\title{
Drug Effect of Thulium(III)-Arsenazo III Complex on Herring Sperm DNA
}

\author{
Hongbo Li $\left(\mathbb{D}\right.$, Shutao Lei, Yongqiong Tang, Liyuan Zou, Hongqin Hu, and Suqin Wang $\mathbb{i}^{\circ}$ \\ Key Laboratory of Functional Small Organic Molecule, Ministry of Education, College of Chemistry and Chemical Engineering, \\ Jiangxi Normal University, Nanchang 330022, China
}

Correspondence should be addressed to Hongbo Li; lihongbo112@126.com and Suqin Wang; wangsuqin163@163.com

Received 22 April 2018; Revised 27 July 2018; Accepted 8 August 2018; Published 18 September 2018

Academic Editor: Marcelino Maneiro

Copyright (c) 2018 Hongbo Li et al. This is an open access article distributed under the Creative Commons Attribution License, which permits unrestricted use, distribution, and reproduction in any medium, provided the original work is properly cited.

To assess the potential cytostatic properties of the thulium(III)-arsenazo III complex as a probe of rare earth complex antitumor drugs, the interaction information of the thulium(III)-arsenazo III complex with DNA was obtained by using spectroscopy, viscosity measurements, and voltammetric methods. The thermodynamic functions demonstrated that the binding constants of the thulium(III)-arsenazo III complex with DNA were $K_{298.15 \mathrm{~K}}^{\theta}=4.84 \times 10^{6} \mathrm{~L} \cdot \mathrm{mol}^{-1}$ and $K_{308.15 \mathrm{~K}}^{\theta}=4.48 \times 10^{6} \mathrm{~L} \cdot \mathrm{mol}^{-1}$, and the binding process was enthalpy driven. The increase in relative viscosity of DNA with the addition of the thulium(III)-arsenazo III complex and the results from Scatchard and voltammetric methods showed that the interaction mode between the thulium(III)arsenazo III complex and DNA was groove binding along with weak intercalative binding.

\section{Introduction}

As is known to all, DNA is an important genetic substance in organisms which controls the synthesis of protein and expression of the gene. [1] Due to advances in medical technology, DNA has become the target molecule for many antitumor and anticancer drugs in recent years [2]. Interaction of DNA with small molecules is of current interest and significance in many research fields, such as biochemistry, medicinal chemistry, and cancer therapy [3]. A large number of researches have shown that the pharmacological activity of most antitumor drugs is related to the binding mode of DNA. Generally, the interaction modes of small molecules with DNA have been broadly categorized into the following three types including intercalative binding, groove binding, and electrostatic binding [4]. In the majority of situations, the intercalative binding is stronger than the other two binding modes because the intercalative molecule is sandwiched between the aromatic heterocyclic base pairs of DNA [5]. However, depending on particular properties of the ligands and other conditions of binding, groove binders may bind to DNA more tightly than typical intercalators. Thus, due to the interaction mechanism of small molecules with DNA being revealed, it will help to improve the efficacy of antitumor basing on molecular biological theory and provide a guidance for the development of the novel, highly efficient, and low toxic antitumor drugs $[6,7]$.

Since the rare earth ion has anti-inflammatory, bactericidal, and analgesic properties, it can effectively combine with nucleic acids which are superior to transition metals and small molecules [6]. In addition, their toxicities are decreased and the pharmaceutical properties have been improved when they coordinate with a ligand [8]. So, the interaction of rare earth metal complexes with DNA has received much attention in recent years, and these results are promising for their application in the development of new antitumor drugs [1]. Arsenazo III (ASA) is a bis-azo metalchromogenic reagent which has been in use since 1960 for spectrophotometric determination of metal ions. And now, it continues to attract oncologists' attention $[9,10]$, and the chemical structure of ASA is shown in Figure 1. As the researchers all know, ASA has been widely used in the analysis of rare earth elements [11]. A large number of studies have demonstrated the complexation behavior of ASA with rare earth elements $[12,13]$, but the interaction of 
<smiles>O=S(=O)(O)c1cc2cc(S(=O)(=O)O)c(N=Nc3ccccc3[As](=O)(O)O)c(O)c2cc1N=Nc1ccccc1[W](=O)(O)O</smiles>

FIgURE 1: The chemical structure of arsenazo III.

ASA-rare earth metal complexes with DNA has seldom been reported until now. In addition, formation of earth metal complexes can not only improve the pharmaceutical properties of rare earth metals but also produce better synergistic effects of rare earth elements and small organic molecules. Hence, the researchers have done more meticulous research about the interaction of the thulium(III)arsenazo III (Tm(III)-ASA) complex with DNA.

A number of techniques have been applied for investigation of the interaction of small molecules with DNA, including UV spectrophotometry [14-16], fluorescence spectroscopy [17-20], circular dichroism spectroscopy $[21,22]$, mass spectrometry [23], electrochemical methods [24], voltammetry [25], X-ray diffraction [26], and dynamic viscosity measurements [27]. Among these techniques, UV spectrophotometry and fluorescence spectroscopy are regarded as the more effective methods because they are simple, rapid, and sensitive [28]. Furthermore, UV-vis and fluorescence measurements could obtain information related to the binding mechanisms between small molecules and DNA, such as molar ratio, binding modes, binding constants, quenching rate constants, and thermodynamic parameters [29].

In this article, the researchers have characterized the composition of Tm(III)-ASA complex and the interaction parameter of Tm(III)-ASA complex with DNA by UV-vis spectrophotometry, fluorescence spectroscopy, viscosity measurements, and voltammetry. The binding mode, binding ratio, thermodynamic parameters, and binding constants were also obtained. Additionally, we selected acridine orange $(\mathrm{AO})$ and $4 \mathrm{~S}$ green plus nucleic acid stain (4S Green) as the probe, which can intercalate into the base pairs of double-stranded DNA, and the fluorescence intensity is enhanced, and they offer lower toxicity, higher stability, and convenience of using [27]. From this study, the researchers believe that it will provide useful information on the interaction mechanism of rare earth metal complexes with DNA and guide for the synthesis of new anticancer and antitumor drugs.

\section{Experiments and Methods}

2.1. Materials and Reagents. Herring sperm DNA (Sigma Chem. Co., USA) was used without further purification, and its stock solution was prepared by dissolving an appropriate amount of DNA in $50.0 \mathrm{mM}$ tris- $\mathrm{HCl}$ buffer solution $(\mathrm{pH}$ 7.40) and storing at $4^{\circ} \mathrm{C}$ before being used. The concentration of DNA in stock solution was determined by UV absorption at $260 \mathrm{~nm}$ using a molar absorption coefficient, $\varepsilon_{260}=6600 \mathrm{~L} \cdot \mathrm{mol}^{-1} \cdot \mathrm{cm}^{-1}$ [30]. Purity of DNA was checked by monitoring the absorbance at $260 \mathrm{~nm}$ and $280 \mathrm{~nm}$. When it was the ratio $>1.8$ of $A_{260} / A_{280}$, it indicates that DNA was free from protein [31]. All samples were dissolved in $50.0 \mathrm{mM}$ tris- $\mathrm{HCl}$ buffer solution $(\mathrm{pH} 7.40)$. The stock solution of $\mathrm{Tm}^{3+}\left(2.00 \times 10^{-3} \mathrm{~mol} \cdot \mathrm{L}^{-1}\right)$ was prepared by dissolving $\mathrm{Tm}_{2} \mathrm{O}_{3}$ (99.95\%; Fourth Reagent Factory, Shanghai, China) in hydrochloric acid and heating it until nearly being dried, then diluting with ultrapure water. A stock solution $\left(5.00 \times 10^{-4} \mathrm{~mol} \cdot \mathrm{L}^{-1}\right)$ of arsenazo III (Jinsui Bio-Technology, Shanghai, China) was prepared by dissolving its crystals in ultrapure water. Acridine orange $(\mathrm{AO})$ dye stock solution $\left(5.00 \times 10^{-4} \mathrm{~mol} \cdot \mathrm{L}^{-1}\right)$ was prepared by dissolving its crystals (Sigma Chem. Co., USA) in ultrapure water. 4S green plus nucleic acid stain was purchased from Sigma-Aldrich Corporation (America). All chemicals were of the analytical grade without further purification. All solutions were prepared with ultrapure water which was obtained through a Millipore Milli-Q water purification system (Billerica, Bedford, MA) and had an electrical resistivity of $>18.25 \mathrm{M} \Omega \cdot \mathrm{cm}$.

2.2. Apparatus. The absorption spectra were measured on a Lambda 35 spectrophotometer (Perkin Elmer Company, America) using a $1.0 \mathrm{~cm}$ cuvette. The fluorescence spectra were measured using a LS-55 fluorophotometer (Perkin Elmer Company, America). The slits for excitation and emission were both set at $5.0 \mathrm{~nm}$ and the scan rate at $240 \mathrm{~nm} \cdot \mathrm{min}^{-1}$. The viscosity measurements were carried out using an NDJ-79 viscosity meter (Yinhua Flowmeter Co. Ltd., Hangzhou, China). The cyclic voltammetric (CV) experiments were carried out with a CHI820B electrochemical workstation ( $\mathrm{CH}$ Instrument Company, Texas, America). A FE20 pH meter (Mettler-Toledo Instruments, Shanghai, China) was used to $\mathrm{pH}$ measurements. All experiments, unless otherwise specified, were carried out at room temperature $\left(25 \pm 1^{\circ} \mathrm{C}\right)$.

\subsection{Procedures}

2.3.1. UV-Vis Spectral Measurements. The UV-vis absorption spectra of ASA, Tm(III), and its mixture with DNA were measured in the wavelength range of 300 to $800 \mathrm{~nm}$ at room temperature. The solution in the cuvette was mixed thoroughly prior to each scan, and the volume affection was so small that it could be ignored. In addition, all experiments used the $50.0 \mathrm{mM}$ tris- $\mathrm{HCl}$ buffer solution ( $\mathrm{pH} 7.40$ ) as the reference solution.

2.3.2. Fluorescence Spectral Measurements. The different concentrations of the Tm(III)-ASA complex, 4S Green, or $\mathrm{AO}$ were added directly into the quartz cuvette that contains the DNA solution. The solution in the cuvette was mixed 
uniformly before each being scanned, and the volume affection could be ignored for small change in volume. The slits for excitation and emission were both set at $5.0 \mathrm{~nm}$ and $\lambda_{\mathrm{ex}}=490 \mathrm{~nm}$, respectively, and the scan rate at $240 \mathrm{~nm} \cdot \mathrm{min}^{-1}$.

2.3.3. Viscosity Measurement. Viscosity measurement was measured by using a viscometer at room temperature, and the viscometer was placed in the thermostat for keeping a constant temperature. Different amounts of the Tm(III)ASA complex was added into the viscometer while keeping DNA concentration constant. The flow times of the samples were repeatedly measured with an accuracy of $\pm 0.2^{\circ} \mathrm{C}$, and each sample was measured three times at least. The data were presented as $\ln \left(\eta / \eta_{0}\right)$ versus $c_{\mathrm{Tm}(\mathrm{III}) \text {-ASA }} / c_{\mathrm{DNA}}$, where $\eta$ and $\eta_{0}$ are the viscosity of DNA in the presence and the absence of the Tm(III)-ASA complex.

2.3.4. Cyclic Voltammetric Measurement. The cyclic voltammetric (CV) experiment was carried out with an electrochemical workstation which used three-electrode system at room temperature. A glassy carbon (GC) disk electrode of $3.0 \mathrm{~mm}$ diameter was used as the working electrode, a platinum sheet as the counter electrode, and a saturated calomel electrode (SCE) as the reference electrode. Cyclic voltammograms of electrodes were obtained in $50.0 \mathrm{mM}$ tris- $\mathrm{HCl}$ buffer solution ( $\mathrm{pH}$ 7.40) with the potential range between $-0.5 \mathrm{~V}$ and $0.5 \mathrm{~V}$ and a sweep rate of $50.0 \mathrm{mV} \cdot \mathrm{s}^{-1}$.

\section{Results and Discussion}

3.1. UV-Vis Spectroscopic Characteristics. Numerous research studies showed that the absorption spectrum changed when the small molecule interacted with DNA and formed a new complex [32]. Figure 2 shows that the absorption spectra of ASA, DNA, Tm(III), DNA-ASA, DNA-Tm(III), Tm(III)-ASA complex, and Tm(III)-ASA-DNA system at a certain concentration were obtained using a UV-vis spectrometer. By seeing the spectrogram, there were not absorption peaks of DNA (curve f), Tm(III) (curve g), and DNA-Tm(III) system (curve e) in the wavelength of the visible region. The maximum absorption of ASA (curve c) was located at approximately $550 \mathrm{~nm}$, but the absorbance of DNA-ASA (curve d) decreased apparently, it indicated the formation of DNA-ASA supramolecular complexes. However, when Tm(III) was added in ASA solution, the maximum absorption of Tm(III)-ASA (curve b) was located in about $605 \mathrm{~nm}$ with an apparently red shift of $55 \mathrm{~nm}$, and peak height increased remarkably, which indicated the formation of the Tm(III)-ASA complex and then, added the same amount of DNA to the system, the absorbance of DNA-Tm(III)-ASA (curve a) system increased remarkably at $603 \mathrm{~nm}$, with a slight blue shift of $2 \mathrm{~nm}$. The result showed that a binding interaction between the Tm(III)-ASA complex and DNA had occurred.

3.2. Spectroscopic Study of Interaction between Thulium(III) and ASA III. The absorption spectra of the ASA with the

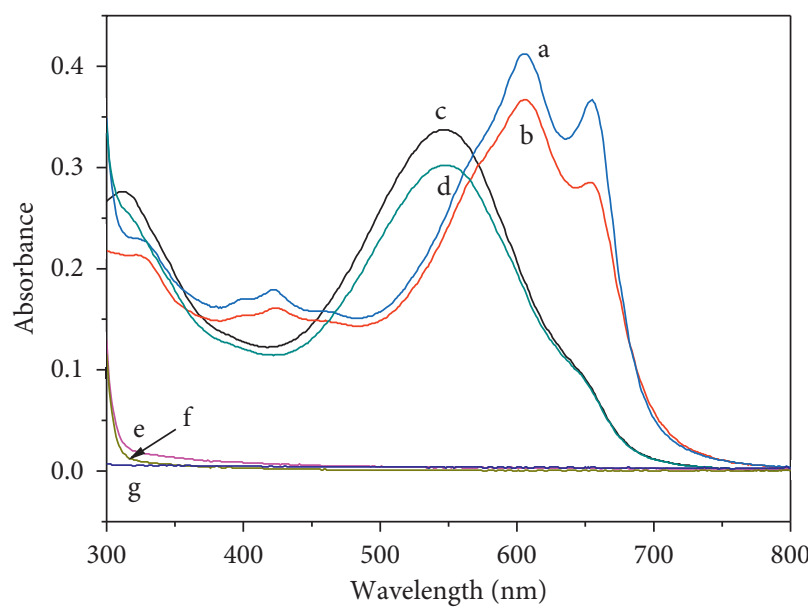

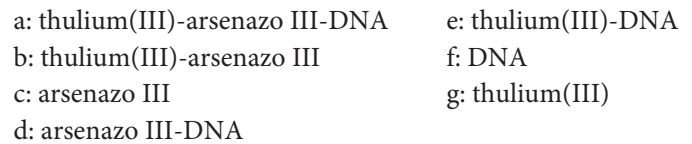

FIgURE 2: Absorption spectra of seven kinds of samples ( $\mathrm{pH} 7.40$ ). $c_{\text {Arsenazo III }}=5 \times 10^{-5} \mathrm{~mol} \cdot \mathrm{L}^{-1} ; c_{\text {Thulium (III) }}=1 \times 10^{-4} \mathrm{~mol} \cdot \mathrm{L}^{-1} ; c_{\text {DNA }}=$ $1 \times 10^{-5} \mathrm{~mol} \cdot \mathrm{L}^{-1}$.

addition of $\operatorname{Tm}(\mathrm{III})$ are shown in Figure 3(a). When the concentration of Tm(III) was increased, the absorption peak intensity of ASA at approximately $550 \mathrm{~nm}$ exhibited that it gradually decreased with a slight red shift. In addition, two new absorption peaks were, respectively, formed at about $605 \mathrm{~nm}$ and $655 \mathrm{~nm}$. An isosbestic point at $575 \mathrm{~nm}$ also provided an evidence for the new Tm(III)-ASA complex formation.

In order to obtain the stoichiometry of Tm(III)-ASA complex, the molar ratio method was executed based on the absorbance intensity of Tm(III)-ASA complex at $605 \mathrm{~nm}$. The mole ratio [33] plots of ASA with Tm(III) are shown in Figure 3(b), and the binding ratio of the complex was $n_{\mathrm{Tm}(\mathrm{III})}: n_{\mathrm{ASA}}=2: 3$. According to the Lambert-Beer law, $A=\varepsilon b c$, where $A$ is the absorbance intensity of Tm(III)-ASA and $c$ is the concentration of $\operatorname{Tm}(\mathrm{III})$-ASA. The apparent molar absorption coefficient of Tm(III)-ASA complex was determined, $\varepsilon=7.94 \times 10^{3} \mathrm{~L} \cdot \mathrm{mol}^{-1} \cdot \mathrm{cm}^{-1}$.

\subsection{Spectroscopic Study of Thulium(III)-Arsenazo III Complex} Interaction with DNA. The absorption spectra of Tm(III)ASA complex in the presence of different concentrations of DNA are shown in Figure 4(a). From Figure 4(a), the absorption peak of the Tm(III)-ASA complex at about $550 \mathrm{~nm}$. With the addition of DNA, the absorbance peak of Tm(III)ASA complex decreased gradually, and a red shift was observed from 550 to $560 \mathrm{~nm}$ which leaded to hypochromic effect. In addition, two new absorption peaks, respectively, appeared at about $605 \mathrm{~nm}$ and $655 \mathrm{~nm}$. It indicated that the Tm(III)-ASA complex could strongly interact with DNA.

The molar ratio method was used to obtained the stoichiometry of the Tm(III)-ASA complex with DNA at $655 \mathrm{~nm}$. Figure 4(b) showed that the binding ratio of the complex was $n_{\operatorname{Tm}(\mathrm{III})-\mathrm{ASA}}: n_{\mathrm{DNA}}=12: 1$. According to the 


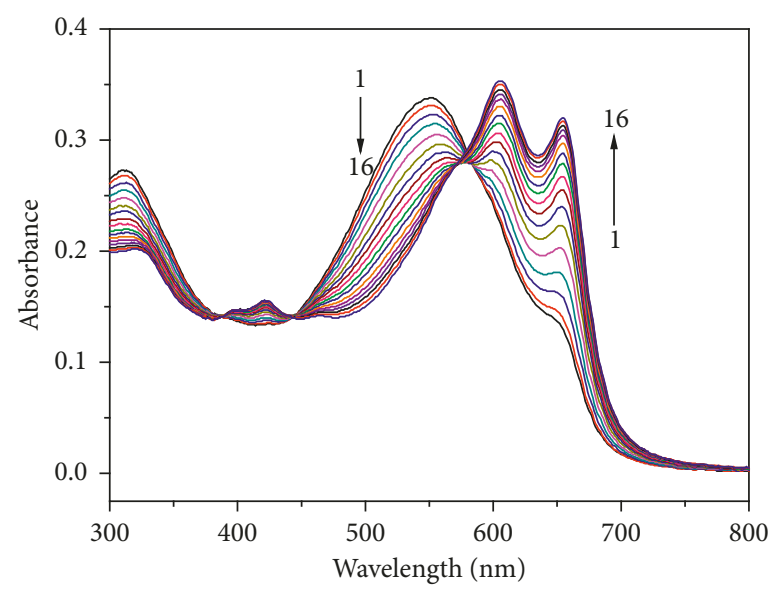

(a)

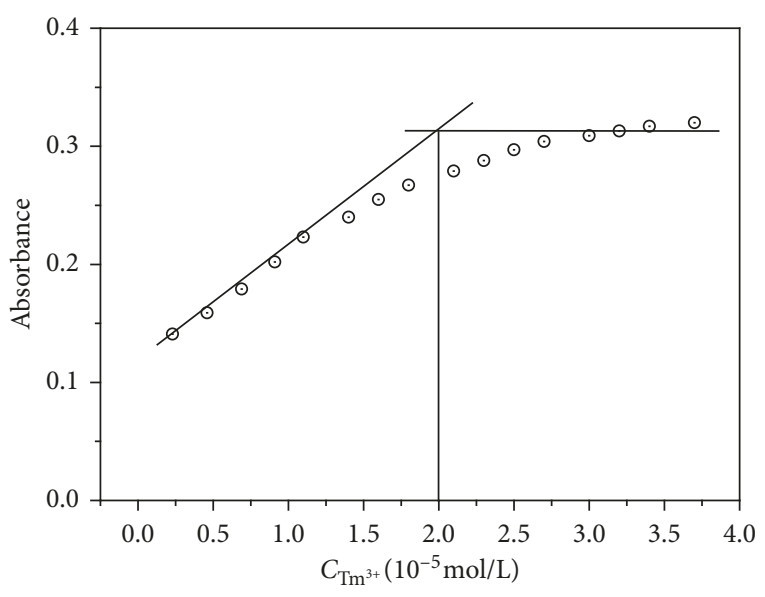

(b)

FIGURE 3: (a) Absorption spectra of ASA in different concentrations of thulium (III); (b) molar ratio of thulium(III)-arsenazo III complex at $\lambda=605 \mathrm{~nm}(\mathrm{pH} 7.40) . c_{\text {Arsenazo III }}=5 \times 10^{-5} \mathrm{~mol} \cdot \mathrm{L}^{-1} ; c_{\text {Thulium (III) }}=1 \times 10^{-4} \mathrm{~mol} \cdot \mathrm{L}^{-1} ; c_{\text {DNA }}=1 \times 10^{-5} \mathrm{~mol} \cdot \mathrm{L}^{-1}(10 \mu \mathrm{L} \mathrm{per} \mathrm{scan,} 1-16: 0-150 \mu \mathrm{L})$.

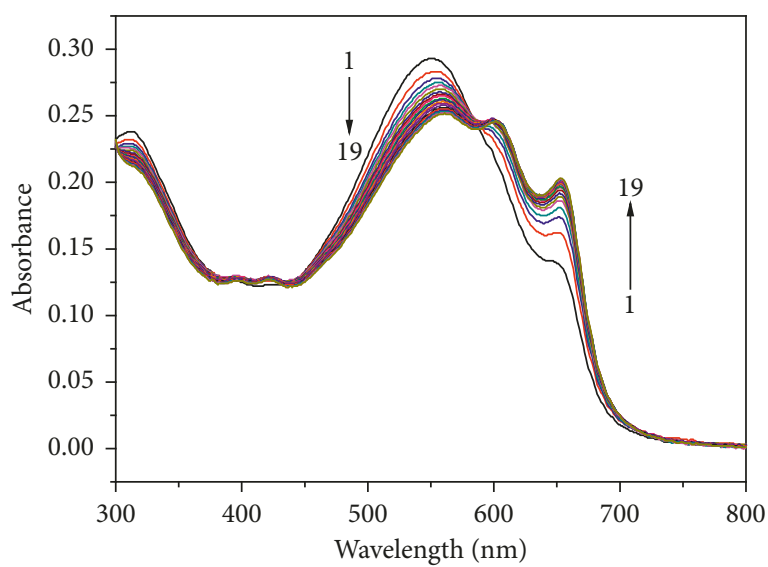

(a)

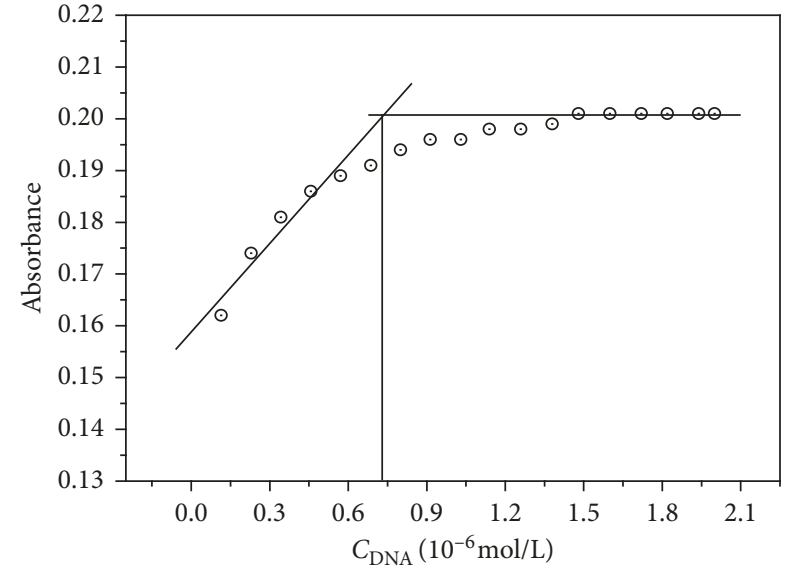

(b)

FIgURE 4: (a) Absorption spectra of thulium(III)-arsenazo III complex in different concentrations of DNA; (b) molar ratio of DNA-thulium (III)-arsenazo III system at $\lambda=655 \mathrm{~nm}(\mathrm{pH} 7.40)$. $c_{\text {Arsenazo III }}=5 \times 10^{-5} \mathrm{~mol} \cdot \mathrm{L}^{-1} ; c_{\text {Thulium (III) }}=1 \times 10^{-4} \mathrm{~mol} \cdot \mathrm{L}^{-1} ; c_{\mathrm{DNA}}=1 \times 10^{-5} \mathrm{~mol} \cdot \mathrm{L}^{-1}$. $(10 \mu \mathrm{L}$ per scan, $1-19: 0-180 \mu \mathrm{L})$.

Lambert-Beer law $A=\varepsilon b c$, and the apparent molar absorption coefficient, $\quad \varepsilon=4.71 \times 10^{5} \mathrm{~L} \cdot \mathrm{mol}^{-1} \cdot \mathrm{cm}^{-1} \quad$ was calculated.

3.4. Thermodynamic Analysis. The value of the binding constant $K$ of Tm(III)-ASA complex with DNA was expressed by the double reciprocal equation [34]:

$$
\frac{1}{\left(A_{0}-A\right)}=\frac{1}{A_{0}}+\frac{1}{\left(K \times A_{0} \times c_{\mathrm{DNA}}\right)}
$$

where $A_{0}$ and $A$ are the absorbance of Tm(III)-ASA complex in the absence and in the presence of DNA, respectively. $K$ is the binding constant of Tm(III)-ASA complex with DNA and $c_{\text {DNA }}$ is the concentration of DNA. The double-reciprocal plots of $1 /\left(A_{0}-A\right)$ versus $1 / c_{\text {DNA }}$ were linear at $298.15 \mathrm{~K}$ and $308.15 \mathrm{~K}$, respectively. The binding constants $K$ were calculated from the ratio of the intercept on the vertical (Figure 5):
$K_{298.15 \mathrm{~K}}^{\theta}=4.84 \times 10^{6} \mathrm{~L} \cdot \mathrm{mol}^{-1} \quad$ and $\quad K_{308.15 \mathrm{~K}}^{\theta}=4.48 \times 10^{6} \mathrm{~L}$. $\mathrm{mol}^{-1}$. The interaction forces between small molecules and DNA mainly include hydrophobic force, electrostatic interaction, Van der Waals force, and hydrogen bonds [35]. According to Ross' view [36], the main binding force can be judged by the standard enthalpy change $\left(\Delta_{r} H_{m}^{\theta}\right)$ and the standard entropy change $\left(\Delta_{r} S_{m}^{\theta}\right)$. If the temperature was a little changed, the $\Delta_{r} H_{m}^{\theta}$ could be regarded as a constant, and then, the value of $\Delta_{r} H_{m}^{\theta}$ is calculated from the van't Hoff equation [37]:

$$
\ln \frac{K_{2}^{\theta}}{K_{1}^{\theta}}=\frac{-\Delta_{r} H_{m}^{\theta}\left(1 / T_{2}-1 / T_{1}\right)}{R},
$$

where $K_{1}^{\theta}$ and $K_{2}^{\theta}$ are the standard binding constants of Tm (III)-ASA complex with DNA at $298.15 \mathrm{~K}$ and $308.15 \mathrm{~K}$, respectively and $R$ is gas constant. So, the value of $\Delta_{r} H_{m}^{\theta}$ is obtained, $\Delta_{r} H_{m}^{\theta}=-5.903 \times 10^{3} \mathrm{~J} \cdot \mathrm{mol}^{-1}$. According to the 


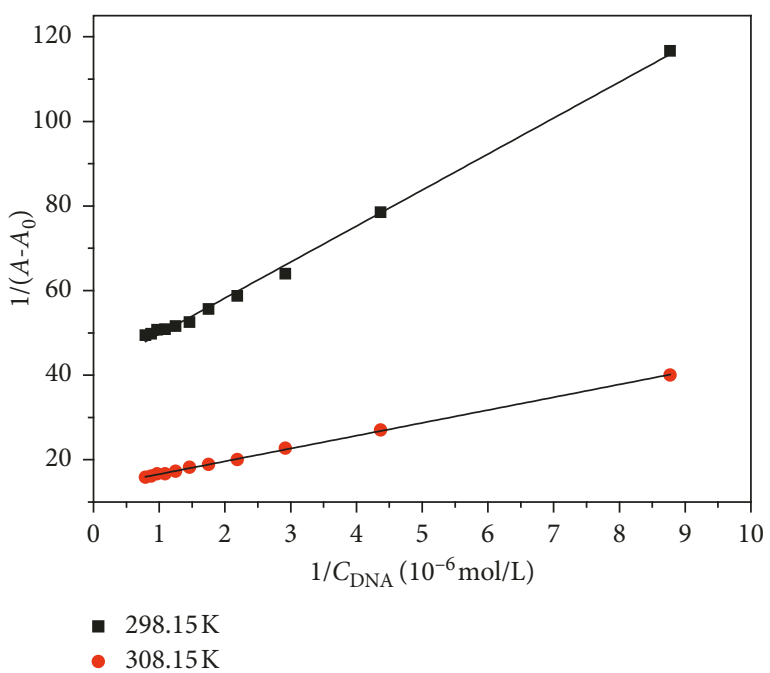

Figure 5: Double reciprocal plots of DNA-thulium(III)-arsenazo III system $(\mathrm{pH} 7.40 ; \lambda=655 \mathrm{~nm}) . c_{\text {Arsenazo III }}=5 \times 10^{-5} \mathrm{~mol} \cdot \mathrm{L}^{-1}$; $c_{\text {Thulium (III) }}=1 \times 10^{-4} \mathrm{~mol} \cdot \mathrm{L}^{-1} ; c_{\text {DNA }}=1 \times 10^{-5} \mathrm{~mol} \cdot \mathrm{L}^{-1} \quad(10 \mu \mathrm{L}$ per scan, 1-19: 0-180 $\mu \mathrm{L}$ ).

Equations (3) and (4), the standard free energy change $\Delta_{r} G_{m}^{\theta}$ and the standard entropy change $\Delta_{r} S_{m}^{\theta}$ are calculated, respectively.

$$
\begin{aligned}
& \Delta_{r} G_{m}^{\theta}=-R T \ln K^{\theta}, \\
& \Delta_{r} G_{m}^{\theta}=\Delta_{r} H_{m}^{\theta}-T \Delta_{r} S_{m}^{\theta} .
\end{aligned}
$$

From the Equation (3), the standard molar reaction Gibbs free energy $\Delta_{r} G_{m}^{\theta}$ can be obtained, $\Delta_{r} G_{m}^{\theta}=-3.82 \times 10^{4} \mathrm{~J} \cdot \mathrm{mol}^{-1}$. So, the value of $\Delta_{r} S_{m}^{\theta}$ is $108.33 \mathrm{~J} \cdot \mathrm{mol}^{-1} \cdot \mathrm{K}^{-1}$. Due to the $\Delta_{r} G_{m}^{\theta}<0$, it showed that the binding process of Tm(III)-ASA complex with DNA is always spontaneous. However, the enthalpy contribution was calculated as $-5.903 \mathrm{~kJ} / \mathrm{mol}$ for $\mathrm{dG}=-38.2 \mathrm{~kJ} / \mathrm{mol}$. It follows that the entropic contribution equals to $38-5.9 \mathrm{~kJ} / \mathrm{mol}$ which therefore appears to be dominating over the enthalpic contribution.

3.5. Fluorescence Spectrophotometry for Thulium(III)Arsenazo III Complex and $4 S$ Green Probe Competitive Interaction with DNA. The direct use of the fluorescence emission of DNA has a major limitation in the study of its related properties because the fluorescence of DNA is very weak. $4 \mathrm{~S}$ green plus nucleic acid stain ( $4 \mathrm{~S}$ Green) is a kind of cationic dye, for its planar aromatic chromophore, which can intercalate into the base pairs of double-stranded DNA and the fluorescence intensity is greatly enhanced. So, it can act as an indicator of intercalation. On excitation at $490 \mathrm{~nm}$, $4 \mathrm{~S}$ Green has a strong fluorescence emission peaked at $525 \mathrm{~nm}$. Figure 6(a) showed that the maximum emission intensity of $4 \mathrm{~S}$ Green gradually increased with increasing concentration of DNA, and a slight blue shift took place. This result indicated that $4 \mathrm{~S}$ Green could intercalate into the base pair of DNA and form a new complex.

The fluorescence intensity of the DNA-4S Green system gradually decreased with the increased concentration of the
$\operatorname{Tm}(\mathrm{III})$-ASA complex at $525 \mathrm{~nm}$ (Figure 6(b)). Thus, there was a competition mode between $4 \mathrm{~S}$ Green and the Tm(III)ASA complex with DNA, which led to the change of fluorescence of spectrum [38]. Figure 6(b) shows that the fluorescence of the DNA-4S Green system is efficiently quenched by adding the Tm(III)-ASA complex. These phenomena proved that the Tm(III)-ASA complex intercalated into the double helix of the DNA by exchanging with $4 \mathrm{~S}$ Green. In addition, it also indicated that the binding mode of the Tm(III)-ASA complex with DNA was the same as $4 \mathrm{~S}$ Green with DNA. [39].

3.6. Scatchard Method. The fluorescence Scatchard analysis is usually used to study the influence of AO to the DNA-Tm (III)-ASA system and confirm the binding modes [40]. Scatchard equation [41] expresses the binding mode of the DNA-Tm(III)-ASA complex in the presence of different concentrations of $\mathrm{AO}$ probe.

$$
\frac{r_{\mathrm{AO}}}{c_{\mathrm{AO}}}=K\left(n-r_{\mathrm{AO}}\right)
$$

where $r_{\mathrm{AO}}$ refers to the molecular amount of bound $\mathrm{AO}$ to total DNA concentration; $c_{\mathrm{AO}}$ is the concentration of free $\mathrm{AO}$; $n$ is the number of binding sites of DNA; and $K$ is the intrinsic binding constant of DNA-AO. There are different concentrations of the $\mathrm{Tm}(\mathrm{III})$-ASA complex $\left(R_{\mathrm{t}}=\mathrm{c}_{\mathrm{Tm}}\right.$ (III)-ASA $/ \mathrm{c}_{\mathrm{DNA}}$; a, $R_{\mathrm{t}}=0.00 ; \mathrm{b}, R_{\mathrm{t}}=0.20 ; \mathrm{c}, R_{\mathrm{t}}=0.40$; and $\mathrm{d}, R_{\mathrm{t}}=0.60$, respectively), and then the samples were titrated by AO solution, and the fluorescence intensity was measured. If the values of $n$ were equal at different $R_{\mathrm{t}}$, the Tm(III)-ASA complex would be regarded as an intercalation binding mode, and it would be regarded as a disintercalation binding mode if the values of $K$ were equal. However, there were mix binding modes that contained disintercalation and intercalation binding if both the values of $n$ and $K$ were changed. [42,43] In order to testify if there was electrostatic binding between the $\mathrm{Tm}$ (III)-ASA complex and DNA, the researcher used $0.05 \mathrm{~mol} / \mathrm{L} \mathrm{NaCl}$ in the Scatchard studies. The Scatchard plots in the absence of $\mathrm{NaCl}$ and the presence of $\mathrm{NaCl}$ are shown in Figures. 7(a) and 7(b), respectively.

According to the Scatchard equation (5) and from the Scatchard plots, the values of $n$ and $K$ were calculated. From Table 1, if the value of $n$ is increased in the presence of $\mathrm{NaCl}$, these results indicated that there was no electrostatic binding [44], but disintercalation binding mode-groove interaction existed in the DNA-Tm(III)ASA system because of the variation of the parameters $n$ and $K$ that are different from each other. In addition, a part of the free AO molecules would combine with DNA molecules, the binding between $\operatorname{Tm}$ (III)-ASA and DNA was weak, and the values of $n$ increased. Thus, the interaction mode between the Tm(III)ASA complex and DNA contained groove and weak intercalation bindings.

3.7. Viscosity Measurements. Viscosity measurement is one of the most effective methods to judge the binding modes between small molecules and DNA than spectral measurements $[45,46]$. Generally speaking, classical intercalation 


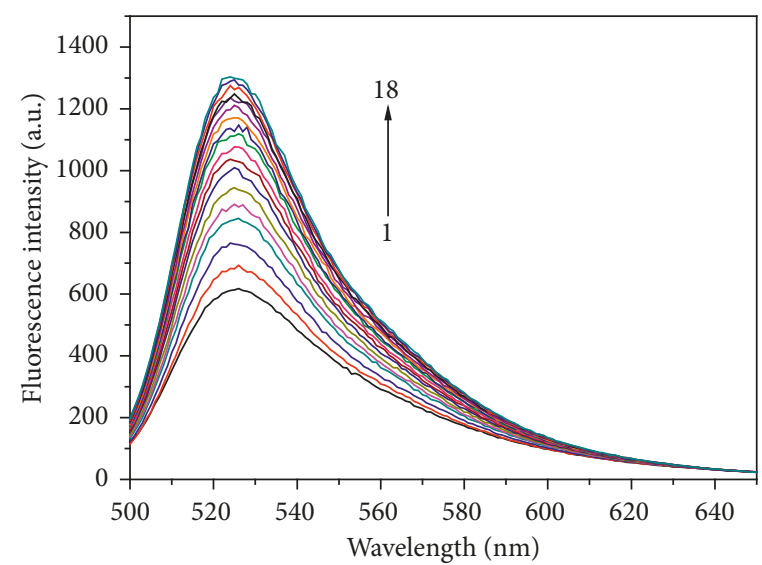

(a)

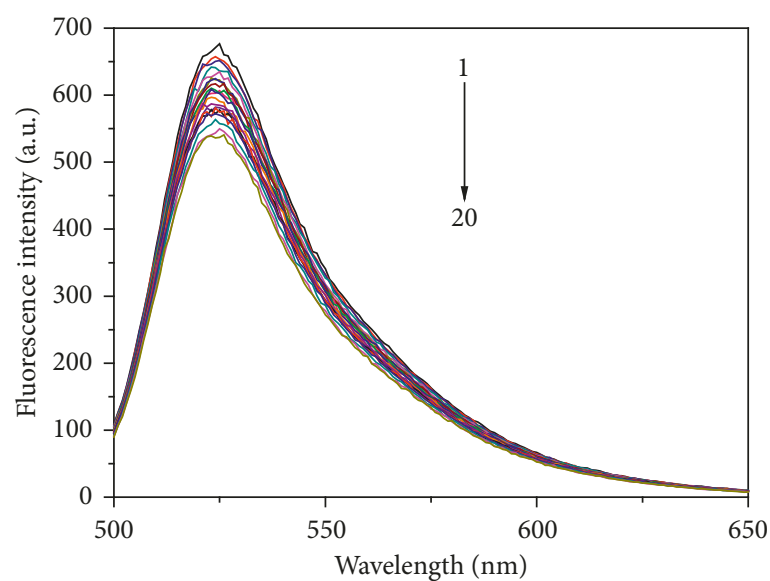

(b)

FIgURE 6: (a) Fluorescence spectra of $4 \mathrm{~S}$ Green in different concentrations of DNA $\left(\mathrm{pH} 7.40 ; \lambda_{\mathrm{ex}}=490 \mathrm{~nm}, \lambda_{\mathrm{em}}=525 \mathrm{~nm}\right)$. $c_{4 \mathrm{~S} \text { Green }}=2.5 \times 10^{-6} \mathrm{~mol} \cdot \mathrm{L}^{-1} ; c_{\mathrm{DNA}}=1 \times 10^{-5} \mathrm{~mol} \cdot \mathrm{L}^{-1}(10 \mu \mathrm{L}$ per scan, $1-18: 0-170 \mu \mathrm{L})$; (b) fluorescence spectra of DNA-4S Green system in different concentrations of thulium(III)-arsenazo III complex $\left(\mathrm{pH} 7.40 ; \lambda_{\mathrm{ex}}=490 \mathrm{~nm}, \lambda_{\mathrm{em}}=525 \mathrm{~nm}\right) . \quad c_{4 \mathrm{~S}} \mathrm{Green}=2.5 \times 10^{-6} \mathrm{~mol} \cdot \mathrm{L}^{-1}$; $c_{\text {DNA }}=1 \times 10^{-6} \mathrm{~mol} \cdot \mathrm{L}^{-1} ; c_{\text {Thulium (III)-arsenazo III }}=5.00 \times 10^{-4} \mathrm{~mol} \cdot \mathrm{L}^{-1}(10 \mu \mathrm{L}$ per scan, $1-18: 0-170 \mu \mathrm{L})$.

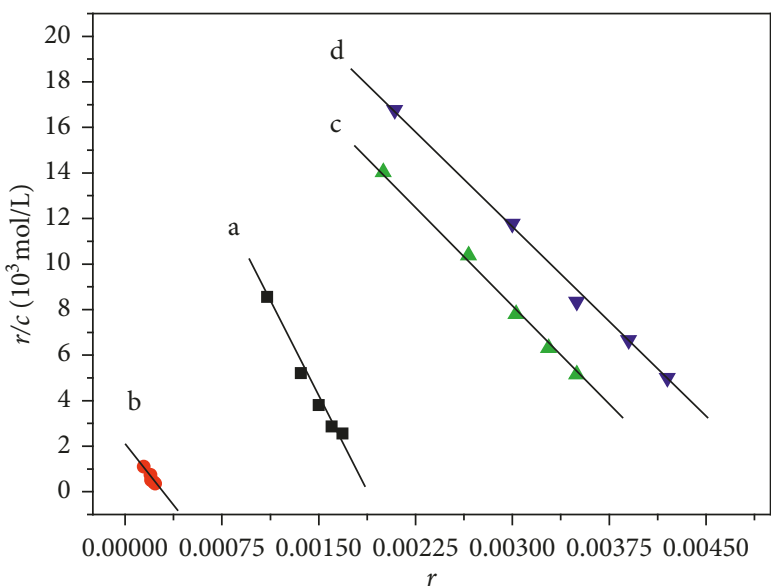

(a)

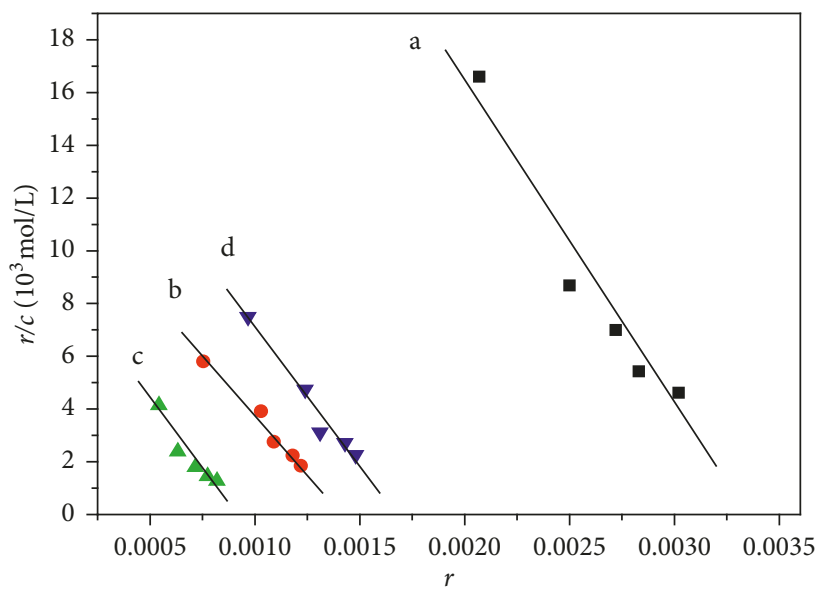

(b)

FIgURE 7: Scatchard plots of the interaction between thulium(III)-arsenazo III and DNA in different concentrations of AO. (a) Without $\mathrm{NaCl}$; (b) with $\mathrm{NaCl}(\mathrm{pH}=7.40) . c_{\text {Thulium (III)-arsenazo III }}=8.30 \times 10^{-6} \mathrm{~mol} / \mathrm{L} ; c_{\mathrm{DNA}}=4.00 \times 10^{-6} \mathrm{~mol} / \mathrm{L} ; c_{\mathrm{AO}}=4.00 \times 10^{-5} \mathrm{~mol} / \mathrm{L}(10 \mu \mathrm{L} \mathrm{per} \mathrm{can})$;

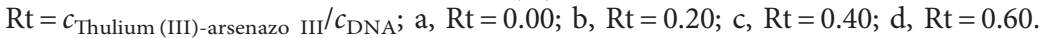

TABle 1: Data from the Scatchard equation on the interaction between thulium(III)-arsenazo III complex and DNA.

\begin{tabular}{lccccc}
\hline Curve & $\mathcal{c}_{\text {Thulium(III)-arsenazo III } / c_{\text {DNA }}}$ & $\mathrm{NaCl}(\mathrm{mol} / \mathrm{L})$ & Scatchard plot values & $K(\mathrm{~L} / \mathrm{mol})$ \\
\hline \multirow{2}{*}{$\mathrm{a}$} & \multirow{2}{*}{0.00} & 0.00 & $r / c=1.99 \times 10^{4}-1.05 \times 10^{7} \mathrm{r}$ & $1.05 \times 10^{7}$ & 0.00169 \\
& & 0.05 & $r / c=4.23 \times 10^{4}-1.28 \times 10^{7} \mathrm{r}$ & $1.28 \times 10^{7}$ & 0.00207 \\
\hline \multirow{2}{*}{$\mathrm{b}$} & \multirow{2}{*}{0.20} & 0.00 & $r / c=2.35 \times 10^{3}-8.63 \times 10^{6} \mathrm{r}$ & $8.63 \times 10^{6}$ & 0.00027 \\
& \multirow{2}{*}{0.40} & 0.05 & $r / c=1.24 \times 10^{4}-8.58 \times 10^{6} \mathrm{r}$ & $8.58 \times 10^{6}$ & 0.00122 \\
\hline \multirow{2}{*}{$\mathrm{c}$} & \multirow{2}{*}{0.60} & 0.00 & $r / c=2.61 \times 10^{4}-6.01 \times 10^{6} \mathrm{r}$ & $6.01 \times 10^{6}$ & 0.00404 \\
& \multirow{2}{*}{$\mathrm{d}$} & 0.05 & $r / c=9.14 \times 10^{3}-9.93 \times 10^{6} \mathrm{r}$ & $9.93 \times 10^{6}$ & 0.00082 \\
\hline
\end{tabular}

leads to an increase in the viscosity of DNA solution because the length of the double-helical structure of the DNA is increased for the insertion ligand. Groove and electrostatic bindings cause no obvious increase in DNA viscosity. Figure 8 shows that the value of relative viscosity was enhanced by increasing the concentrations of the Tm(III)-ASA complex. 


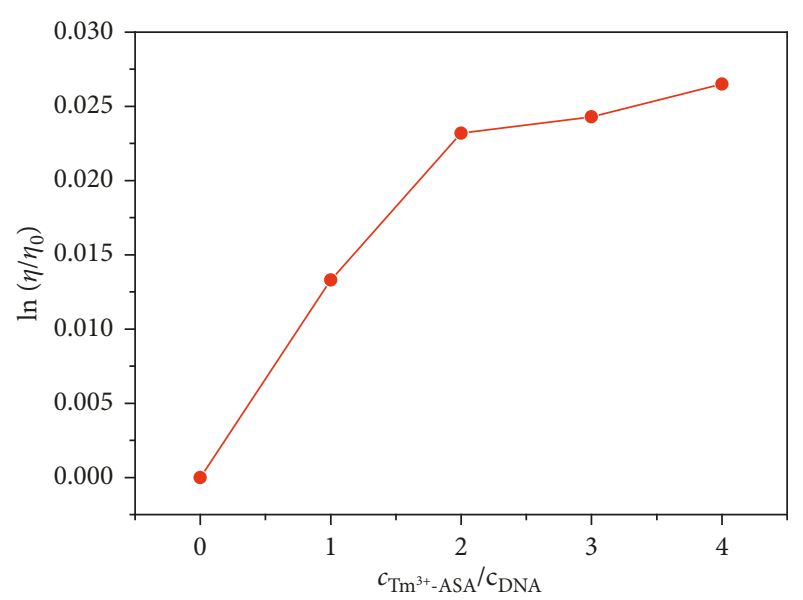

FIgURE 8: Effect viscosity of thulium(III)-arsenazo III on DNA $(\mathrm{pH}=7.40) . c_{\mathrm{DNA}}=2.00 \times 10^{-5} \mathrm{~mol} / \mathrm{L} ; \mathcal{c}_{\text {Thulium }}$ (III)-arsenazo $\mathrm{III} / \mathcal{c}_{\mathrm{DNA}}=0$, $1,2,3,4$.

This result indicated that the interaction method of the Tm (III)-ASA complex with DNA should be intercalation binding.

3.8. Cyclic Voltammetric Measurements. The electrochemical study on the interaction of Tm(III)-ASA complex with DNA has seldom been presented although numerous studies on the interaction of some drugs with DNA have been reported [47]. In order to investigate the interaction of DNA with the Tm(III)-ASA complex, cyclic voltammograms of electrodes in $50.0 \mathrm{mM}$ tris- $\mathrm{HCl}$ buffer solution ( $\mathrm{pH} 7.40$ ) which contains a certain concentration of Tm(III)-ASA complex in the presence of DNA and absence of DNA were used for a voltammetric test. As seen in Figure 9, it was noteworthy that a pair redox peaks appeared, and the peaks potential at about $-0.136 \mathrm{~V}$ and $0.231 \mathrm{~V}$ where produced by the Tm(III)-ASA complex (curve a). After DNA addition, the oxidation peak potential of the corresponding complex shifted towards the more positive potential, and the peak current increased (curve b). This suggested that the Tm(III)ASA complex interacts with DNA. Because numerous studies showed that if there was a shift towards the negative potential, interaction between DNA and complex is mainly electrostatic. On the contrary, when the shift of peak happens towards the positive potential, there is the interaction of small molecules and DNA $[48,49]$. In this study, the peak potential appears at more positive values in the presence of DNA, which also indicated that an intercalation binding should be the interaction mode of the Tm(III)-ASA complex with DNA.

\section{Conclusion}

In summary, the interaction of Tm(III)-ASA complex with DNA was demonstrated in detail. Hypochromicity and red shift of the absorption spectra of Tm(III)-ASA complex were obtained in the presence of DNA which provided an evidence for the new Tm(III)-ASA-DNA complex formation. A competitive reaction of the Tm(III)-ASA complex and

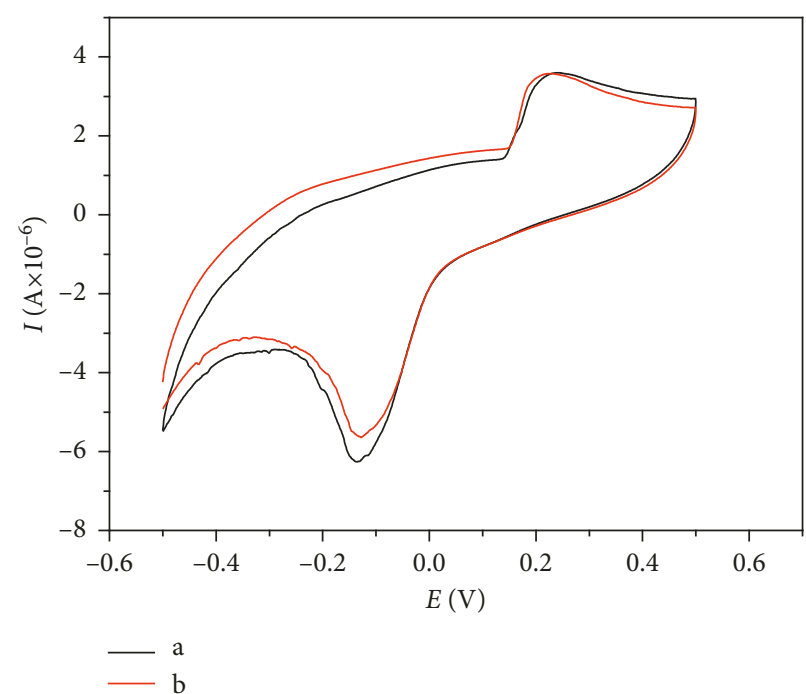

FIgURE 9: Cyclic voltammograms of thulium(III)-arsenazo III complex in absence of and presence of DNA (50.0 mM tris- $\mathrm{HCl}$ buffer, $\mathrm{pH} 7.40)$. $c_{\mathrm{DNA}}=1 \times 10^{-5} \mathrm{~mol} \cdot \mathrm{L}^{-1} ; c_{\text {Thulium }}$ (III)-arsenazo $\mathrm{III}=5.00 \times 10^{-6} \mathrm{~mol} \cdot \mathrm{L}^{-1}$; scan rate $=50 \mathrm{mV} / \mathrm{s}$.

4S Green with DNA was monitored by fluorescence spectroscopy, and it indicated that the Tm(III)-ASA complex could intercalate into the double helix of DNA, but the intercalation binding mode was weaker than $4 \mathrm{~S}$ Green. The researchers believed that the interaction information between Tm(III)-ASA complex and DNA would provide a useful reference on the interaction mechanism of rare earth complexes with DNA, which would be beneficial to design highly efficient anticancer and antitumor drugs for most of the researchers.

\section{Data Availability}

The data used to support the findings of this study are available from the corresponding author upon request.

\section{Conflicts of Interest}

The authors declare that they have no conflicts of interest.

\section{Acknowledgments}

This work was supported by NSFC (Grant nos. 21565015 and 21663014), the Foundation of Jiangxi Educational Committee (GJJ150363), the State Key Laboratory of Chemical Biosensing \& Chemometrics (Z2015022), and the Key Laboratory of Functional Small organic molecule (KLFS-KF201425).

\section{References}

[1] G. W. Zhang, J. B. Guo, N. Zhao, and J. R. Wang, "Study of interaction between kaempferol-Eu ${ }^{3+}$ complex and DNA with the use of the Neutral Red dye as a fluorescence probe," Sensors and Actuators B: Chemical, vol. 144, no. 1, pp. 239246, 2010. 
[2] A. Lauria, R. Bonsignore, A. Terenzi et al., "Nickel(II), copper (II) and zinc(II) metallo-intercalators: structural details of the DNA-binding by a combined experimental and computational investigation," Dalton Transactions, vol. 43, no. 16, pp. 6108-6119, 2014.

[3] Z. Asadi, N. Nasrollahi, H. Karbalaei-Heidari et al., "Investigation of the complex structure, comparative DNAbinding and DNA cleavage of two water-soluble mononuclear lanthanum(III) complexes and cytotoxic activity of chitosan-coated magnetic nanoparticles as drug delivery for the complexes," Spectrochimica Acta Part A: Molecular and Biomolecular Spectroscopy, vol. 178, pp. 125-135, 2017.

[4] N. Zhao, X. M. Wang, H. Z. A. Pan, Y. M. Hu, and L. S. Ding, "Spectroscopic studies on the interaction between tryptophan-erbium(III) complex and herring sperm DNA," Spectrochimica Acta Part A: Molecular and Biomolecular Spectroscopy, vol. 75, no. 5, pp. 1435-1442, 2010.

[5] H. J. Sun, A. L. Wang, H. B. Chu, and Y. L. Zhao, "Fluorescent studies on the interaction of DNA and ternary lanthanide complexes with cinnamic acid-phenanthroline and antibacterial activities testing," Luminescence, vol. 30, no. 2, pp. 131-136, 2015.

[6] G. Zhang, J. Guo, J. Pan, X. Chen, and J. Wang, "Spectroscopic studies on the interaction of morin-Eu(III) complex with calf thymus DNA," Journal of Molecular Structure, vol. 923, no. 1-3, pp. 114-119, 2009.

[7] G. J. Chen, X. Qiao, C. Y. Gao et al., "DNA binding, photoinduced DNA cleavage and cell cytotoxicity studies of a family of light rare earth complexes," Journal of Inorganic Biochemistry, vol. 109, pp. 90-96, 2012.

[8] J. Sangster, "C-Na (Carbon-Sodium) system," Journal of Phase Equilibria and Diffusion, vol. 28, no. 6, pp. 571-579, 2007.

[9] E. Singer and M. Matucha, "Erfahrungen mit der bestimmung von Uran in Erzen und Gesteinen mit Arsenazo III," Fresenius' Zeitschrift für analytische Chemie, vol. 191, no. 4, pp. 248-253, 1962.

[10] K. Matharu, S. K. Mittal, S. K. Ashok Kumar, and S. K. Sahoo, "Selectivity enhancement of Arsenazo(III) reagent towards heavier lanthanides using polyaminocarboxylic acids: a spectrophotometric study," Spectrochimica Acta Part A: Molecular and Biomolecular Spectroscopy, vol. 145, pp. 165-175, 2015.

[11] H. Rohwer, N. Collier, and E. Hosten, "Spectrophotometric study of arsenazo III and its interactions with lanthanides," Analytica Chimica Acta, vol. 314, no. 3, pp. 219-223, 1995.

[12] E. Hosten and H. Rohwer, "Interaction of anions with arsenazo III-lanthanide (III) complexes," Analytica Chimica Acta, vol. 345, no. 1-3, pp. 227-233, 1997.

[13] N. N. Basargin, V. M. Ivanov, V. V. Kuznetsov, and A. V. Mikhailova, "40 years since the discovery of the arsenazo III reagent," Journal of Analytical Chemistry, vol. 55, no. 3, pp. 204-210, 2000.

[14] N. K. Modukuru, K. J. Snow, B. S. Perrin, A. Bhambhani, M. Duff, and C. V. Kumar, "Tuning the DNA binding modes of an anthracene derivative with salt," Journal of Photochemistry and Photobiology A: Chemistry, vol. 177, no. 1, pp. 43-54, 2006.

[15] X. L. Xiong, N. Zhao, and X. M. Wang, "Interaction between tryptophan-Sm(III) complex and DNA with the use of a acridine orange dye fluorophor probe," Luminescence, vol. 31, no. 1, pp. 210-216, 2016.

[16] N. Ganji, A. Rambabu, N. Vamsikrishna, S. Daravath, and Shivaraj, "Copper(II) complexes with isoxazole Schiff bases: synthesis, spectroscopic investigation, DNA binding and nuclease activities, antioxidant and antimicrobial studies," Journal of Molecular Structure, vol. 1173, pp. 173-182, 2018.

[17] J. F. Li and C. Dong, "Study on the interaction of morphine chloride with deoxyribonucleic acid by fluorescence method," Spectrochimica Acta Part A: Molecular and Biomolecular Spectroscopy, vol. 71, no. 5, pp. 1938-1943, 2009.

[18] N. Ataci, E. Ozcelik, and N. Arsu, "Spectrophotometric study on binding of 2-thioxanthone acetic acid with ct-DNA," Spectrochimica Acta Part A: Molecular and Biomolecular Spectroscopy, vol. 204, pp. 281-286, 2018.

[19] E. Grueso, P. Perez-Tejeda, R. M. Giráldez-Pérez, R. PradoGotor, and F. Muriel-Delgado, "Ethanol effect on gold nanoparticle aggregation state and its implication in the interaction mechanism with DNA," Journal of Colloid and Interface Science, vol. 529, pp. 65-76, 2018.

[20] T. Thirunavukkarasu, H. A. Sparkes, and K. Natarajan, "Quinoline based Pd(II) complexes: synthesis, characterization and evaluation of DNA/protein binding, molecular docking and in vitro anticancer activity," Inorganica Chimica Acta, vol. 482, pp. 229-239, 2018.

[21] Mudasir, N. Yoshioka, and H. Inoue, "DNA binding of iron (II) mixed-ligand complexes containing 1,10-phenanthroline and 4,7-diphenyl-1,10-phenanthroline," Journal of Inorganic Biochemistry, vol. 77, no. 3-4, pp. 239-247, 1999.

[22] Y. Zhao, Z. Li, H. Li, S. Wang, and M. Niu, "Synthesis, crystal structure, DNA binding and in vitro cytotoxicity studies of $\mathrm{Zn}$ (II) complexes derived from amino-alcohol schiff-bases," Inorganica Chimica Acta, vol. 482, pp. 136-143, 2018.

[23] A. Kapur, J. L. Beck, and M. M. Sheil, "Observation of daunomycin and nogalamycin complexes with duplex DNA using electrospray ionisation mass spectrometry," Rapid Communications in Mass Spectrometry, vol. 13, no. 24, pp. 2489-2497, 1999.

[24] X. Jiang and X. Lin, "Voltammetry of the interaction of metronidazole with DNA and its analytical applications," Bioelectrochemistry, vol. 68, no. 2, pp. 206-212, 2006.

[25] S. Q. Liu, M. L. Cao, and S. L. Dong, "Electrochemical and Ultraviolet-visible spectroscopic studies on the interaction of deoxyribonucleic acid with vitamin B6," Bioelectrochemistry, vol. 74, no. 1, pp. 164-169, 2008.

[26] M. Carcelli, P. Mazza, C. Pelizzi, G. Pelizzi, and F. Zani, "Antimicrobial and genotoxic activity of 2,6-diacetylpyridine bis(acylhydrazones) and their complexes with some first transition series metal-ions - X-ray crystal-structure of a dinuclear copper(II) complex," Journal of Inorganic Biochemistry, vol. 57, no. 1, pp. 43-62, 1995.

[27] S. Bi, C. Qiao, D. Song et al., "Study of interactions of flavonoids with DNA using acridine orange as a fluorescence probe," Sensors and Actuators B: Chemical, vol. 119, no. 1, pp. 199-208, 2006.

[28] C. Y. Qiao, S. Y. Bi, Y. Sun, D. Q. Song, H. Q. Zhang, and W. H. Zhou, "Study of interactions of anthraquinones with DNA using ethidium bromide as a fluorescence probe," Spectrochimica Acta Part A: Molecular and Biomolecular Spectroscopy, vol. 70, no. 1, pp. 136-143, 2008.

[29] M. Xu, F. J. Chen, L. Huang, P. X. Xi, and Z. Z. Zeng, "Binding of rare earth metal complexes with an ofloxacin derivative to bovine serum albumin and its effect on the conformation of protein," Journal of Luminescence, vol. 131, no. 8, pp. 15571565, 2011.

[30] Y. Ni, S. Du, and S. Kokot, "Interaction between quercetin-copper(II) complex and DNA with the use of the Neutral Red dye fluorophor probe," Analytica Chimica Acta, vol. 584, no. 1, pp. 19-27, 2007. 
[31] S. Mahadevan and M. Palaniandavar, "Spectroscopic and voltammetric studies on copper complexes of 2,9-dimethyl-1,10-phenanthrolines bound to calf thymus DNA," Inorganic Chemistry, vol. 37, no. 4, pp. 693-700, 1998.

[32] L. Z. Zhang and G. Q. Tang, "The binding properties of photosensitizer methylene blue to herring sperm DNA: a spectroscopic study," Journal of Photochemistry and Photobiology B: Biology, vol. 74, no. 2-3, pp. 119-125, 2004.

[33] P. X. Xi, Z. H. Xu, X. H. Liu et al., "Synthesis, characterization, antioxidant activity and DNA-binding studies of three rare Earth (III) complexes with 1-(4-aminoantipyrine)-3-tosylurea ligand," Journal of Fluorescence, vol. 19, no. 1, pp. 63-72, 2009.

[34] A. A. Ouameur, R. Marty, and H. A. Tajmir-Riahi, "Human serum albumin complexes with chlorophyll and chlorophyllin," Biopolymers, vol. 77, no. 3, pp. 129-136, 2005.

[35] H. Ojha, B. M. Murari, S. Anand, M. I. Hassan, F. Ahmad, and N. K. Chaudhury, "Interaction of DNA minor groove binder hoechst 33258 with bovine serum albumin," Chemical \& Pharmaceutical Bulletin, vol. 57, no. 5, pp. 481-486, 2009.

[36] P. D. Ross and S. Subramanian, "Thermodynamics of protein association reactions: forces contributing to stability," Biochemistry, vol. 20, no. 11, pp. 3096-3102, 1981.

[37] G. W. Zhang, X. Hu, and J. H. Pan, "Spectroscopic studies of the interaction between pirimicarb and calf thymus DNA," Spectrochimica Acta Part A: Molecular and Biomolecular Spectroscopy, vol. 78, no. 2, pp. 687-694, 2011.

[38] N. Shahabadi, S. Kashanian, and M. Purfoulad, "DNA interaction studies of a platinum(II) complex, $\mathrm{PtCl}_{2}(\mathrm{NN})$ ( $\mathrm{NN}=4,7$-dimethyl-1,10-phenanthroline), using different instrumental methods," Spectrochimica Acta Part A: Molecular and Biomolecular Spectroscopy, vol. 72, no. 4, pp. 757-761, 2009.

[39] B. Jing, M. Zhang, and T. Shen, "[Ruthenium(II)(bpy $\left.)_{2} \mathrm{~L}\right]^{2+}$, where $\mathrm{L}$ are imidazo[f]-1,10-phenanthrolines: synthesis, photophysics and binding with DNA," Spectrochimica Acta Part A: Molecular and Biomolecular Spectroscopy, vol. 60, no. 11, pp. 2635-2641, 2004.

[40] Y. Gao, J. S. Li, G. X. Huang, L. J. Yan, and Z. Dong, "Spectroscopic studies on the interaction between anthragallol and DNA using of ethidium bromide as a fluorescence probe," Spectrochimica Acta Part A: Molecular and Biomolecular Spectroscopy, vol. 141, pp. 239-243, 2015.

[41] H. Mansuri-Torshizi, R. Mital, T. S. Srivastava, H. Parekh, and M. P. Chitnis, "Synthesis, characterization, and cytotoxic studies of $\alpha$-diimine/1,2-diamine platinum(II) and palladium (II) complexes of selenite and tellurite and binding of some of these complexes to DNA," Journal of Inorganic Biochemistry, vol. 44, no. 4, pp. 239-247, 1991.

[42] Z. G. Zhang and X. D. Dong, "Interaction of DNA with a novel photoactive platinum diimine complex," Biometals, vol. 22, no. 2, pp. 283-288, 2009.

[43] Y. L. Zhou and Y. Z. Li, "Studies of the interaction between poly(diallyldimethyl ammonium chloride) and DNA by spectroscopic methods," Colloids and Surfaces A: Physicochemical and Engineering Aspects, vol. 233, no. 1-3, pp. 129-135, 2004.

[44] S. Tabassum, S. Parveen, and F. Arjmand, "New modulated metallic macrocycles: electrochemistry and their interaction with calf thymus DNA," Acta Biomaterialia, vol. 1, no. 6, pp. 677-689, 2005.

[45] S. Satyanarayana, J. C. Dabrowiak, and J. B. Chaires, "Tris (phenanthroline)ruthenium(II) enantiomer interactions with DNA - mode and specificity of binding," Biochemistry, vol. 32, no. 10, pp. 2573-2584, 1993.
[46] L. B. Liao, H. Y. Zhou, and X. M. Xiao, "Spectroscopic and viscosity study of doxorubicin interaction with DNA," Journal of Molecular Structure, vol. 749, no. 1-3, pp. 108113, 2005.

[47] H. E. Satana, A. D. R. Pontinha, V. C. Diculescu, and A. M. Oliveira-Brett, "Nucleoside analogue electrochemical behaviour and in situ evaluation of DNA-clofarabine interaction," Bioelectrochemistry, vol. 87, pp. 3-8, 2012.

[48] A. Noorbakhsh and A. Salimi, "Development of DNA electrochemical biosensor based on immobilization of ssDNA on the surface of nickel oxide nanoparticles modified glassy carbon electrode," Biosensors and Bioelectronics, vol. 30, no. 1, pp. 188-196, 2011.

[49] I. Kocak, U. Yildiz, B. Coban, and A. Sengul, "DNA-binding studies of complex of $\mathrm{Pt}(\mathrm{bpy})(\mathrm{pip})]^{2+}$ and $[\mathrm{Pt}(\mathrm{bpy})(\mathrm{hpip})]^{2+}$ by electrochemical methods: development of an electrochemical DNA biosensor," Journal of Solid State Electrochemistry, vol. 19, no. 7, pp. 2189-2197, 2015. 

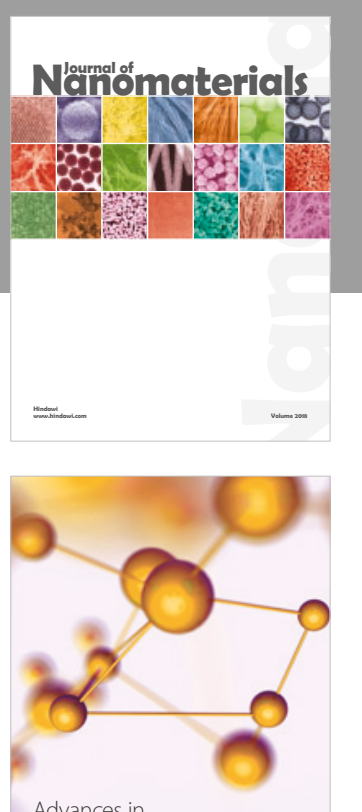

Physical Chemistry
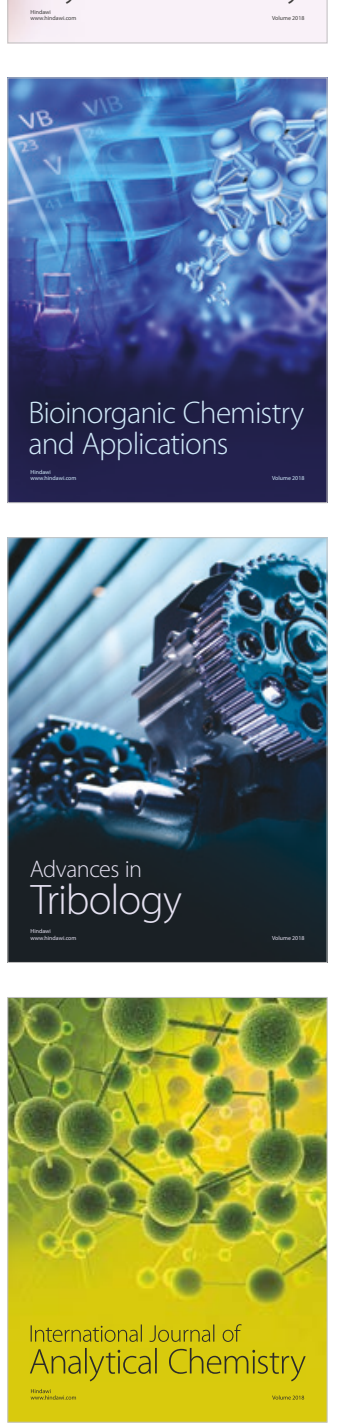

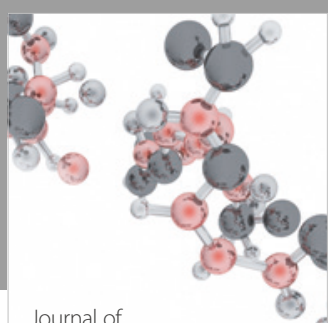

Analytical Methods

in Chemistry

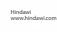

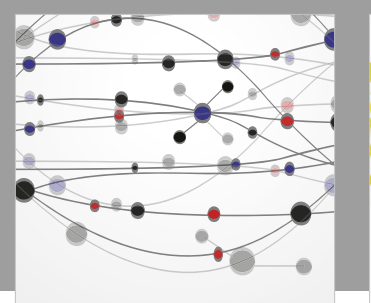

The Scientific World Journal

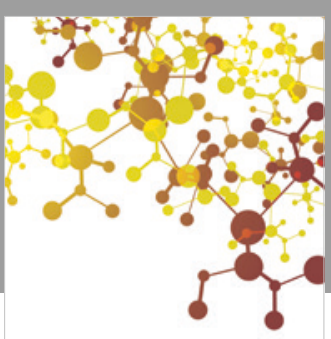

Journal of

Applied Chemistry
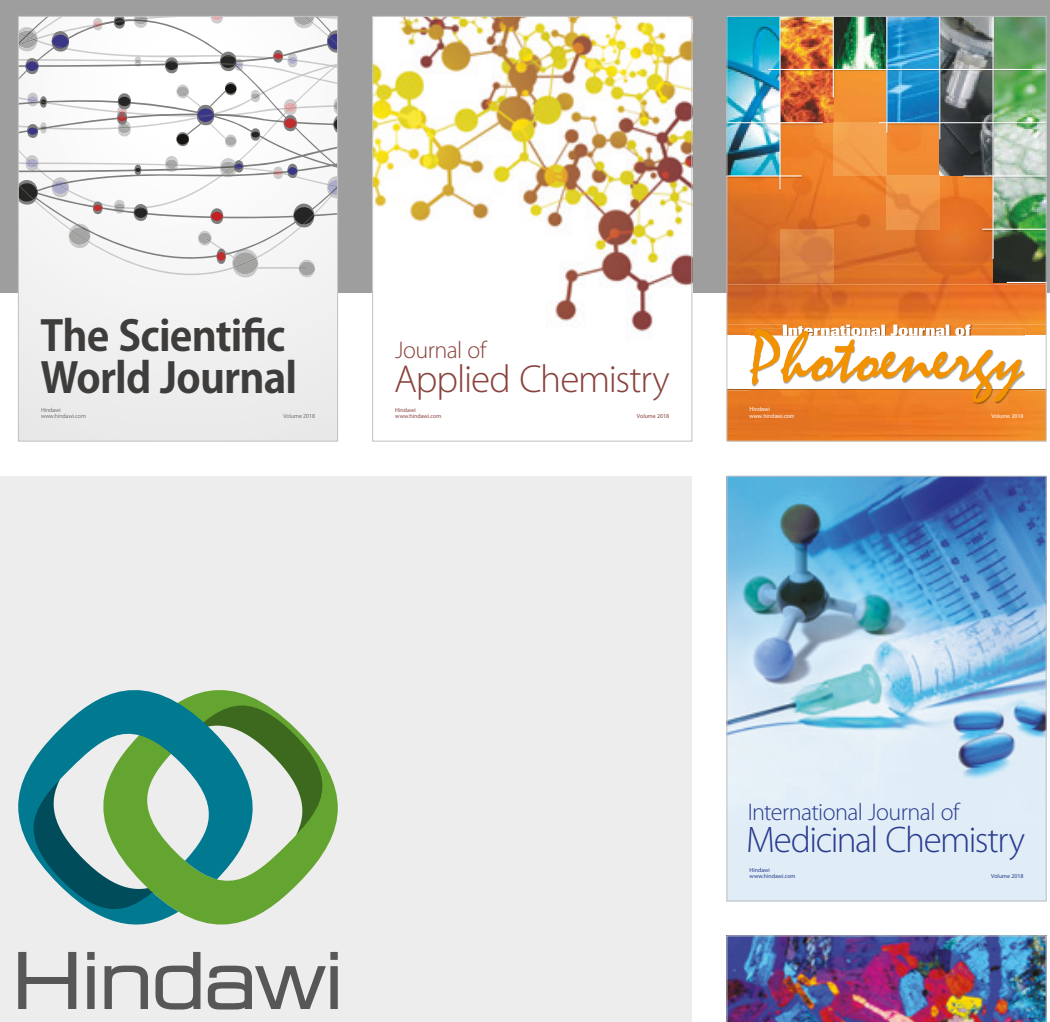

Submit your manuscripts at

www.hindawi.com
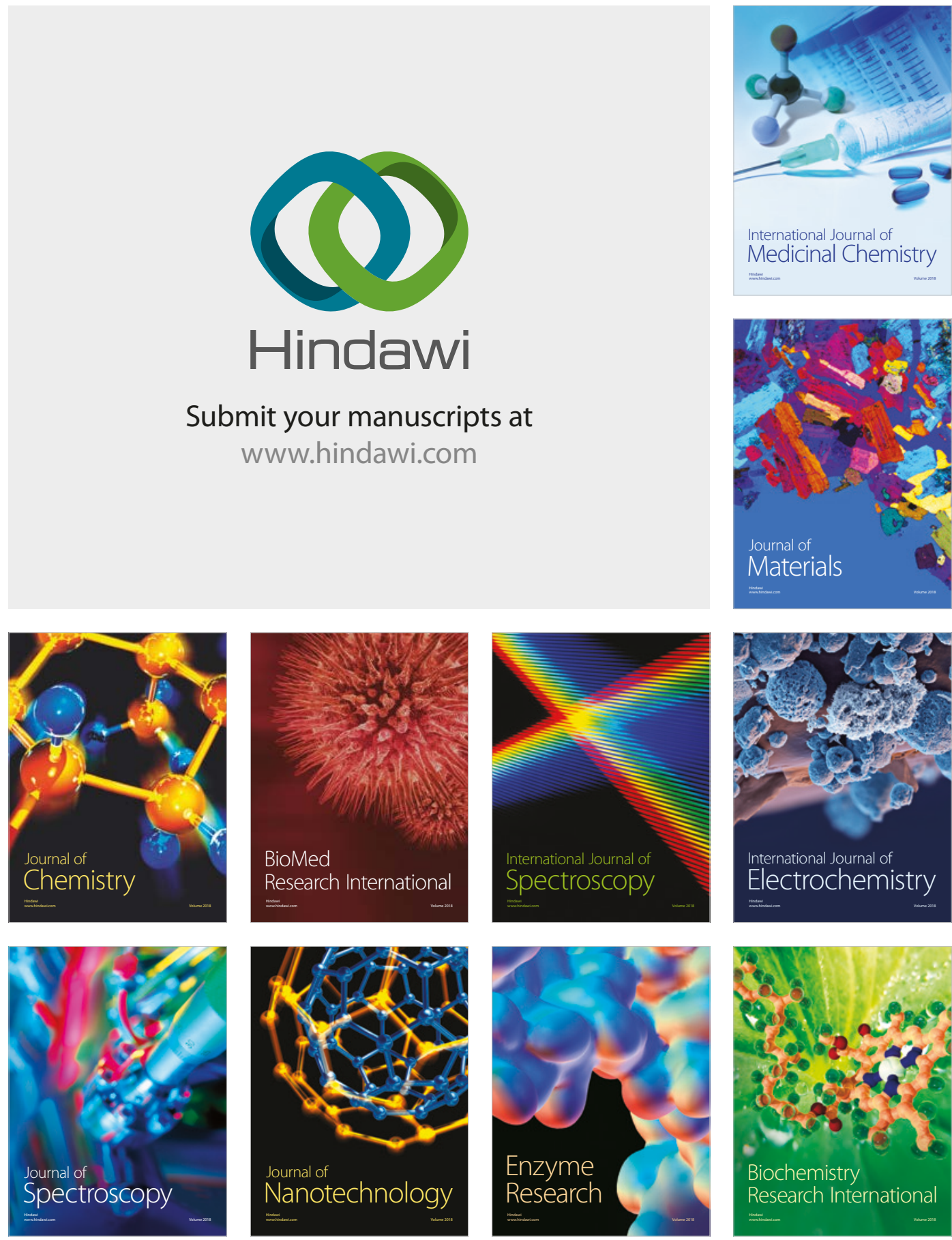
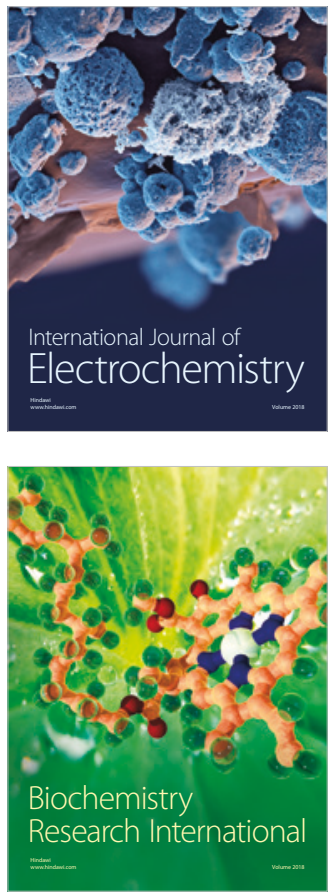